\title{
Benzimidazoles Pharmacodynamics in Equine Strongyles
}

\author{
Laura CĂTAN $\breve{A}^{*}$, Csongor OLÁH, Raul CĂTANĂ, Mihai CERNEA \\ University of Agricultural Sciences and Veterinary Medicine Cluj-Napoca, Faculty of Veterinary \\ Medicine, Calea Manastur 3-5, 400372, Cluj-Napoca, Romania \\ *corresponding author: laura.catana@usamvcluj.ro \\ Bulletin UASVM Veterinary Medicine 73(2) / 2016, \\ Print ISSN 1843-5270; Electronic ISSN 1843-5378 \\ DOI:10.15835/buasvmcn-vm: 12230
}

\begin{abstract}
Our research aimed to assess the effectiveness of four benzimidazoles: albendazole, fenbendazole, mebendazole and thiabendazole against equine strongyles. The tests were performed between March 2015 and May 2016, on samples collected from 20 horses and 8 donkeys living in Harghita County. In vivo, Faecal Egg Count Reduction Test (FECRT) was used to evaluate fenbendazole pharmacodynamics. In vitro, Egg hatch assay (EHA) and Larval development assay (LDA) were used to evaluate the effectiveness of albendazole, fenbendazole, mebendazole and thiabendazole. The predominance of small strongyle species was observed, mostly Cyathostomum type A. In the horse group, before treatment, the average intensity was $1595.5 \mathrm{EPG}$, the maximum value being 4000, and extensivity 55\%. Tested again at 14 days after treatment, all samples were negative. In the donkey group, before treatment, the total number was $6550 \mathrm{EPG}$, intensity of 935.7 and extensivity of $87.5 \%$. 14 days after treatment, the average intensity was 150 and the extensivity 50\%. In the horse group, EHA proved the efficacy of fenbendazole $(0.0192 \%)$, albendazole $(0.3740 \%)$ and thiabendazole $(11.62 \%)$ and a major risk of inducing adaptive phenomena for mebendazole (Y parameter 1009.92). In the donkey group, all benzimidazoles had limited effectiveness: thiabendazole (73.93\%), mebendazole (87.51\%), fenbendazole (94.05\%), albendazole (111.67\%). All benzimidazoles inhibited larval development. For all tested benzimidazoles, the resistance induction predictive comparative risk analysis highlighted the benefit of their use, provided that the treatment protocol allows sufficient contact time.
\end{abstract}

Keywords: benzimidazoles, equines, resistance, strongyles.

\section{INTRODUCTION}

Equine strongyles research and analysis is an important topic due to the very high morbidity (up to 99\%) and the serious, sometimes fatal, repercussions of the infection (Cernea et al., 2010; Cernea et al., 2015; Smith et al., 2015).

Strongyles can alter the animal's behaviour, fertility, physical condition, development, reducing its resistance to other pathogens or even cause death. The large number of species, varying ontogenesis and problems related to diagnosis turn this pathology into a permanent challenge for both veterinarians and equine owners (Cernea et al., 2010; King et al., 1990, Madeira de Carvalho et al., 2014). In addition, the development of anthelmintics resistance, along with the high costs required for finding new drugs force the researchers try to find new ways in approaching diagnosis, treatment and prevention of this pathology (Cernea et al., 2010, Madeira de Carvalho et al., 2003).

Our research aimed to assess the effectiveness of four benzimidazoles: albendazole (ABZ), fenbendazole (FBZ), mebendazole (MBZ) and thiabendazole (TBZ) against equine strongyles.

\section{MATERIAL AND METHODS}

The tests were performed between March 2015 and May 2016 on samples obtained from two groups of animals living in Tomeşti village, Harghita County. 
Group 1 was constituted of 20 horses aged 6 months to 16 years and Group 2 was constituted of 8 donkeys aged 7 months to 19 years.

In vivo, we used the Faecal Egg Count Reduction Test (FECRT) in order to evaluate the fenbendazole effectiveness.

In vitro, in order to evaluate the effectiveness of albendazole, fenbendazole, mebendazole and thiabendazole, two tests were used: Egg Hatch Assay (EHA) and Larval Development Assay (LDA).

Six months prior to this study, in the horse group, ivermectin-based products treatments were carried out. No recorded data regarding the anthelmintic treatments of the donkey group is available. For accuracy, faecal samples were collected directly from the rectal ampulla or immediately after defecation. For each of the collected samples, McMaster and Stoll methods and coprocultures were performed.

FECRT aimed to assess the strongyles intensity and extensivity before (BT) and post-treatment (PT), evaluation of fenbendazole effectiveness in vivo, statistical analysis of the obtained data and identification of the resistant strongyle species.

For EHA, we used serial dilutions from 500 mcg to $0.98 \mathrm{mcg}$ active ingredient $/ \mathrm{ml}$. In order to evaluate the strongyles resistance against benzimidazoles, the following parameters were interrelated: hatching percentage and larval development at the reference concentration, the trendline equation, lethal concentration for $50 \%$ (LC50) and minimum inhibitory concentration (MIC). The trend line equation was calculated automatically allowing interpretation of resistance risk level.

\section{RESULTS AND DISCUSSION}

The stool tests were based on the morphostructural aspects of stage 3 larvae after 14 days of incubation. In the horse group, a predominance of the small strongyle species, especially those of the species Cyathostomum type A was revelead (53.40\%) and Cyathostomum type D (with a percentage of 25). No species of the Strongylidae subfamily were identified, confirming the international data reporting a decreased incidence of these species in horses, along with an increased incidence of small strongyles (Cernea et al., 2010).

In the donkey group, a predominance of small strongyles was observed (Cyathostomum type A
$29.33 \%$, Cyathostomum type D 8\%), though along with larger strongyles, mainly Triodontophorus spp. (1.33\%). Furthermore, a high percentage of Trichostrongylus axei L3 larvae was observed (37.33\%) (Tab. 1). The differences observed between the two equine species, in terms of digestive strongyle populations, can be explained by owners' choice of excluding the donkeys from anthelmintic treatments. Thereby, due to interspecific contamination, the donkey strongyle species constitute a reservoir, unaltered by the anthelmintic treatments. Consequently, regardless of the deworming treatments applied, the horses can be recontaminated with resistant strongyles derived from the untreated donkeys, through cohabitation.

FECRT was performed using a fenbendazolebased product. Before the treatment (BT) individual stool samples were collected. Afterwards, fenbendazole was administered in a dose of 7,5 mg/kg bw. 14 days post-treatment (PT), individual stool samples were collected once again, determining EPG, the intensity and the extensivity level.

In the horse group, the average intensity BT was $1595.5 \mathrm{EPG}$, with a maximum of $4000 \mathrm{EPG}$. The extensivity level BT was 55\%. 14 days PT, all stool samples were negative, reflecting the high efficacy of fenbendazole (Tab. 2).

For the donkey group, results were different. The total EPG determined prior to treatment was 6550, with an intensity of 935.7 and an extensivity of $87.5 \%$. The results, 14 days posttreatment, showed an average intensity of 150 EPG and a decline of the extensivity to 50\% (Tab. 2 ). Fenbendazole proved to be less effective compared to the horse group, even if the donkey group has never been treated with anthelmintics. One may speculate that the donkeys were infected with resistant equine strongyles from the horses.

FECRT statistical interpretation presented a different situation between the two groups. Group 1 had a 100 percentage of reduction, upper and lower limits of $95 \%$ thrust interval being null.

This result highlights the maximum effectiveness of the fenbendazole anthelmintic treatment and the fact that the strongyle population found in horses was not resistant to fenbendazole.

Statistical analysis of the data obtained in the donkey group BT and PT showed a 90.83 
Tab. 1. The infestation degree and the strongyle species found in the two groups

\begin{tabular}{ccccccc}
\hline \multirow{2}{*}{ Species } & \multicolumn{2}{c}{ Group 1 - horses } & \multicolumn{2}{c}{ Group 2 - donkeys } \\
\cline { 2 - 7 } & $\begin{array}{c}\text { Total number of } \\
\text { identified larvae }\end{array}$ & Mean & Percent & $\begin{array}{c}\text { Total number of } \\
\text { identified larvae }\end{array}$ & Mean & Percent \\
\hline Cyathostomum A & 47 & 2.35 & 53.4 & 22 & 2.75 & 29.33 \\
\hline Cyathostomum B & 0 & 0 & 0 & 0 & 0 & 0 \\
\hline Cyathostomum C & 9 & 0.45 & 10.2 & 2 & 0.25 & 2.67 \\
\hline Cyathostomum D & 22 & 1.1 & 25.0 & 6 & 0.75 & 8.00 \\
\hline Cyathostomum E & 0 & 0 & 0 & 0 & 0 & 0 \\
\hline Cyathostomum F & 6 & 0.3 & 6.8 & 5 & 0.63 & 6.67 \\
\hline Cyathostomum G & 3 & 0.15 & 3.4 & 0 & 0 & 0 \\
\hline Cyathostomum H & 0 & 0 & 0 & 0 & 0 & 0 \\
\hline Gyalocephalus capitatus & 1 & 0.05 & 1.1 & 0 & 0 & 0 \\
\hline Oesophagodontus robustus & 0 & 0 & 0 & 0 & 0 & 0 \\
\hline Poteriostomum & 0 & 0 & 0 & 0 & 0 & 0 \\
\hline Crateorstomum acuticadatum & 0 & 0 & 0 & 0 & 0 & 0 \\
\hline Strongylus equines & 0 & 0 & 0 & 0 & 0 & 0 \\
\hline Strongylus edentatus & 0 & 0 & 0 & 0 & 0 & 0 \\
\hline Triodontophorus & 0 & 0 & 0 & 1 & 0.13 & 1.33 \\
\hline Triodontophorus serratus & 0 & 0 & 0 & 0 & 0 & 0 \\
\hline Strongylus vulgaris & 0 & 0 & 0 & 0 & 0 & 0 \\
\hline Trichostrongylus axei & 0 & 0 & 0 & 28 & 3.50 & 37.33 \\
\hline Strongiloides westeri & 0 & 0 & 0 & 0 & 0 \\
\hline Free nematodes & 10 & 0.50 & 11.4 & 11 & 1.38 & 14.67 \\
\hline
\end{tabular}

Tab. 2. The infestation level (EPG) for both groups before treatment (BT) and post-treatment (PT)

\begin{tabular}{|c|c|c|c|c|c|}
\hline Group 1 - horses & EPG BT & EPG PT & Group 2 - donkeys & EPG BT & EPG PT \\
\hline 1 & 4000 & 0 & 1 & 250 & 0 \\
\hline 2 & 1400 & 0 & 2 & 1050 & 0 \\
\hline 3 & 300 & 0 & 3 & 1000 & 0 \\
\hline 4 & 3700 & 0 & 4 & 200 & 200 \\
\hline 5 & 0 & 0 & 5 & 2650 & 100 \\
\hline 6 & 550 & 0 & 6 & 200 & 100 \\
\hline 7 & 700 & 0 & 7 & 1200 & 200 \\
\hline 8 & 800 & 0 & 8 & 0 & 0 \\
\hline 9 & 3400 & 0 & Total & $6550 \mathrm{EPG}$ & $600 \mathrm{OPG}$ \\
\hline 10 & 2500 & 0 & Intensity & 935.7 EPG & $150 \mathrm{OPG}$ \\
\hline 11 & 100 & 0 & Extensivity & $87.50 \%$ & $50 \%$ \\
\hline 12 & 100 & 0 & & & \\
\hline 13 & 0 & 0 & & & \\
\hline 14 & 0 & 0 & & & \\
\hline 15 & 0 & 0 & & & \\
\hline 16 & 0 & 0 & & & \\
\hline 17 & 0 & 0 & & & \\
\hline 18 & 0 & 0 & & & \\
\hline 19 & 0 & 0 & & & \\
\hline 20 & 0 & 0 & & & \\
\hline Total & $17550 \mathrm{EPG}$ & 0 & & & \\
\hline Intensity & $1595.5 \mathrm{EPG}$ & 0 & & & \\
\hline Extensivity & $55 \%$ & 0 & & & \\
\hline
\end{tabular}


percentage of reduction, lower than the minimum percentage accepted (95\%). The confidence interval $95 \%$ was $73 \%$. This data showed that the strongyle population found in the donkey group is resistant to fenbendazole.

The Egg Hatch Assay (EHA) for albendazole in horses showed a hatching percentage of 100 at the reference concentration and the $\mathrm{LC}_{50} 64.32$ $\mathrm{mcg} / \mathrm{ml}$. The statistical analisys of the trend line equation and parameters $\mathrm{a}$ and $\mathrm{b}$ showed the correct hatching percentage of 0.3740 , much lower than the accepted limit of $50 \%$. The maximal value of $\mathrm{Y}$ paramether was -242.42 , drawing a negative tendency for the trend line. All data shows the efficacy of albendazole against the strongyle population found in horses (Tab. 3). Similar results were obtained for fenbendazole as well. The $\mathrm{LC}_{50}$ was $47.31 \mathrm{mcg} / \mathrm{ml}$ and the hatching percentage at the reference concentration was 0.0192 . The Y parameter value was way lower than for albendazole, reaching -257.17 and inducing a negative tendency for the trend line equation. This test confirms the results obtained by FECRT proving the fenbendazole efficacy.

EHA showed a totally different situation for mebendazole compared to albendazole and fenbendazole. The hatching percentage at the reference concentration was 105.10 , showing the weak inhibitory capacity of this active ingredient against strongyle eggs. Even if $\mathrm{LC}_{50}$ had a negative value of $-0.1453 \mathrm{mcg} / \mathrm{ml}$, corroborating the data obtained at the hatching percentage shows us that, in order to obtain a positive value for the $\mathrm{LC}_{50}$, the test should be made with active ingredient concentrations higher than $5 \mathrm{mcg} / \mathrm{ml}$. These results have no practical relevance because of the too high dosage. The trend line equation had a high positive tendency, the maximal value for Y parameter being 1009.92. Integrated analysis of obtained values shows a weak efficacy of mebendazole over strongyle population found in horses and the risk of inducing the adaptive phenomena for this substance.

EHA thiabendazole testing showed the best results, but we have to take in consideration the fact that, because of its capacity to delay egg hatch, this active ingredient was tested only as standard (Cernea et al., 2010). The egg hatch percentage at the reference concentration was 11.62 , with $\mathrm{LC}_{50}$ of $0.0086 \mathrm{mcg} / \mathrm{ml}$ and the trend line equation with a powerful negative tendency ( $\mathrm{Y}$ parameter $=-1,305.1$ ).

Tab. 3. Group 1 EHA results for ABZ and FBZ

\begin{tabular}{cccccccccc}
\hline & & \multicolumn{9}{c}{ ABZ } & \multicolumn{3}{c}{ FBZ } \\
\cline { 3 - 11 } Sample & $\begin{array}{c}\text { A.i. conc. } \\
(\mathrm{mcg} / \mathrm{ml})\end{array}$ & No. of eggs & L1 & Hatching \% & $\begin{array}{c}\text { Trend line } \\
\text { equation }\end{array}$ & No.of eggs & L1 & Hatching \% $\begin{array}{c}\text { Trend line } \\
\text { equation }\end{array}$ \\
\hline 1 & 5.0000 & 150 & 0 & 0.00 & -242.42 & 50 & 50 & 50.00 & -257.17 \\
\hline 2 & 2.5000 & 50 & 0 & 0.00 & -84.25 & 50 & 50 & 50.00 & -100.22 \\
\hline 3 & 1.2500 & 100 & 0 & 0.00 & -5.16 & 0 & 150 & 100.00 & -21.75 \\
\hline 4 & 0.6250 & 150 & 0 & 0.00 & 34.39 & 0 & 150 & 100.00 & 17.49 \\
\hline 5 & 0.3125 & 50 & 100 & 66.67 & 54.16 & 100 & 50 & 33.33 & 37.11 \\
\hline 6 & 0.1563 & 0 & 100 & 100.00 & 64.04 & 100 & 0 & 0.00 & 46.92 \\
\hline 7 & 0.0781 & 0 & 50 & 100.00 & 68.99 & 50 & 0 & 0.00 & 51.83 \\
\hline 8 & 0.0391 & 0 & 100 & 100.00 & 71.46 & 0 & 50 & 100.00 & 54.28 \\
\hline 9 & 0.0195 & 50 & 50 & 50.00 & 72.70 & 0 & 50 & 100.00 & 55.51 \\
\hline 10 & 0.0098 & 50 & 50 & 50.00 & 73.31 & 100 & 0 & 0.00 & 56.11 \\
\hline HCL & 0.0000 & 0 & 100 & 100.00 & 73.93 & 0 & 200 & 100.00 & 56.73 \\
\hline H20 & 0.0000 & 0 & 50 & 100.00 & 0.00 & 100 & 0 & 0.00 & 0.00 \\
\hline Total & & 600 & 600 & 55.56 & & 550 & 750 & 52.78 & \\
\hline
\end{tabular}

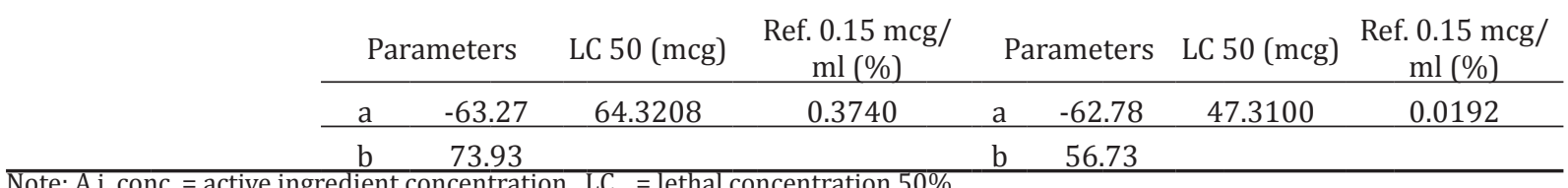


Even if the donkey and the horse group live in the same environment, EHA results for the two groups were totally different. This fact can be explained by the lack of anthelmintic treatments in the donkey group, therefore obtaining different pharmacodynamic results.

The albendazole EHA showed a hatching percentage of 111.67 at the reference concentration and $\mathrm{LC}_{50}-0.54 \mathrm{mcg} / \mathrm{ml}$. The trend line tendency was positive reaching a maximum value of 541.82 (Tab. 5). This results show that albendazole has a reduced efficacy against donkey strongyles, determining a major predictive risk of inducing the resistance phenomena.

Fenbendazole EHA presented 94.05 egg hatching percentage, for the reference concentration, a lot higher than the accepted value of $50 \%$. $\mathrm{LC}_{50}$ was $2.43 \mathrm{mcg} / \mathrm{ml}$, the Y parameter having a value of 0.69 . Even if the trend line had a downward tendency, it is not negative, showing a substantial risk of strongyles to develop adaptative phenomena against this active ingredient.

For mebendazole, in the donkey group, EHA showed an egg hatching percentage of 87.51 at the reference concentration, $\mathrm{LC}_{50}$ being $1.20 \mathrm{mcg} /$ $\mathrm{ml}$. These results showed a reduced efficacy. Even so, compared to albendazole and fenbendazole tests, the risk of strongyles developing adaptive phenomena is lower. The Y parameter showed a value of - 85.15 and the trend line had a negative tendency. For thiabendazole the results were similar, the egg hatching percentage being 73.93 and the $\mathrm{LC}_{50}-0.085 \mu \mathrm{g} / \mathrm{ml}$, with a highly negative trend line tendency $(\mathrm{Y}=-1,840.17)$.

Larval development assay showed similar values in the horse group. MIC value was the same $(0.0489 \mathrm{mcg} / \mathrm{ml})$. The sole difference noted regarded the Y parameter. For albendazole, this value was -525.46 , for fenbendazole -849.21 and -581.11 for mebendazole and thiabendazole (Tab. 7 and 8). In horses, all LDA results showed a good efficacy of benzimidazoles against strongyle eggs and larvae (Tab. 7 and 8).

For all benzimidazoles, the risk of resistance is negligible, for fenbendazole being the lowest (Y -849.21). Therefore, treatment efficacy would be greater if the therapeutic protocol would consider a sequential administration for 2-3 days or repeating it at 7-14 days. For the donkey group, LDA had similar results as for the horse group. The Y parameter had a value of -1104.10 for albendazole, mebendazole and thiabendazole, and lower for fenbendazole (-1226.83) (Tab. 9 and 10).

Tab. 4. Group 1 EHA results for MBZ and TBZ

\begin{tabular}{cccccccccc}
\hline & & \multicolumn{9}{c}{ MBZ } & \multicolumn{3}{c}{ TBZ } \\
\cline { 3 - 11 } Sample no. $\begin{array}{c}\text { A.i. conc. } \\
(\mathrm{mcg} / \mathrm{ml})\end{array}$ & No.of eggs & L1 & Hatching \% & $\begin{array}{c}\text { Trend line } \\
\text { equation }\end{array}$ & No.of eggs & L1 & Hatching \% & $\begin{array}{c}\text { Trend line } \\
\text { equation }\end{array}$ \\
\hline 1 & 5.0000 & 150 & 100 & 40.00 & $1,009.92$ & 500 & 0 & 0.00 & $-1,305.1$ \\
\hline 2 & 2.5000 & 0 & 150 & 100.00 & 543.52 & 500 & 50 & 9.09 & -626.38 \\
\hline 3 & 1.2500 & 100 & 450 & 81.82 & 310.32 & 250 & 0 & 0.00 & -287.01 \\
\hline 4 & 0.6250 & 0 & 100 & 100.00 & 193.72 & 450 & 0 & 0.00 & -117.33 \\
\hline 5 & 0.3125 & 0 & 100 & 100.00 & 135.42 & 400 & 0 & 0.00 & -32.49 \\
\hline 6 & 0.1563 & 0 & 50 & 100.00 & 106.28 & 350 & 0 & 0.00 & 9.92 \\
\hline 7 & 0.0781 & 0 & 100 & 100.00 & 91.69 & 250 & 0 & 0.00 & 31.15 \\
\hline 8 & 0.0391 & 0 & 50 & 100.00 & 84.41 & 250 & 50 & 16.67 & 41.73 \\
\hline 9 & 0.0195 & 100 & 50 & 33.33 & 80.76 & 0 & 100 & 100.00 & 47.06 \\
\hline 10 & 0.0098 & 0 & 50 & 100.00 & 78.95 & 0 & 100 & 100.00 & 49.69 \\
\hline HCL & 0.0000 & 100 & 0 & 0.00 & 77.12 & 0 & 150 & 100.00 & 52.35 \\
\hline H20 & 0.0000 & 50 & 50 & 50.00 & 0.00 & 50 & 100 & 66.67 & 0.00 \\
\hline Total & & 500 & 1250 & 75.43 & & 3000 & 550 & 32.70 & \\
\hline
\end{tabular}

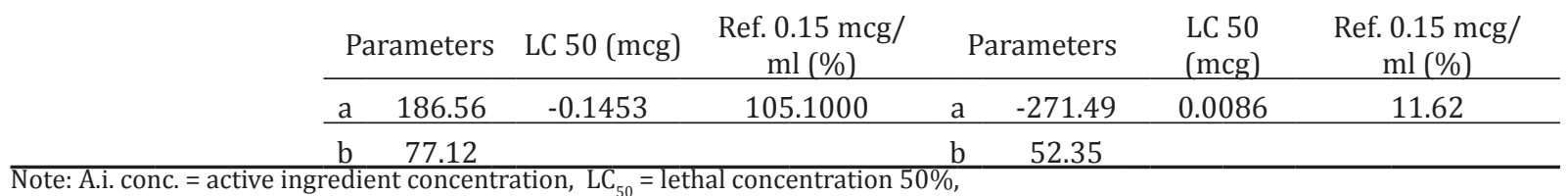


Minimum inhibitory concentration for all benzimidazoles was $0.0489 \mathrm{mcg} / \mathrm{ml}$, proving the fact that, prolonging the contact time between exogenous parasitic forms and anthelmintics, a much higher effectiveness is obtained. At the same time the predictive risk of resistance is greatly diminished, Y paramether showing a highly negative trend line tendency.

Tab. 5. Group 2 EHA results for ABZ and FBZ

\begin{tabular}{cccccccccc}
\hline & & \multicolumn{9}{c}{ ABZ } & \multicolumn{3}{c}{ FBZ } \\
\cline { 3 - 11 } Sample no. $\begin{array}{c}\text { A.i. conc. } \\
(\mathrm{mcg} / \mathrm{ml})\end{array}$ & No. of eggs & L1 & Hatching $\%$ & $\begin{array}{c}\text { Trend line } \\
\text { equation }\end{array}$ & No. of eggs & L1 & Hatching \% $\begin{array}{c}\text { Trend line } \\
\text { equation }\end{array}$ \\
\hline 1 & 5.0000 & 150 & 0 & 0.00 & 541.82 & 0 & 50 & 100.00 & 0.69 \\
\hline 2 & 2.5000 & 0 & 50 & 100.00 & 320.10 & 0 & 100 & 100.00 & 48.82 \\
\hline 3 & 1.2500 & 0 & 50 & 100.00 & 209.23 & 0 & 150 & 100.00 & 72.88 \\
\hline 4 & 0.6250 & 0 & 50 & 100.00 & 153.80 & 0 & 150 & 100.00 & 84.91 \\
\hline 5 & 0.3125 & 0 & 100 & 100.00 & 126.09 & 0 & 50 & 100.00 & 90.92 \\
\hline 6 & 0.1563 & 0 & 100 & 100.00 & 112.23 & 50 & 100 & 66.67 & 93.93 \\
\hline 7 & 0.0781 & 0 & 50 & 100.00 & 105.30 & 0 & 100 & 100.00 & 95.44 \\
\hline 8 & 0.0391 & 0 & 150 & 100.00 & 101.84 & 0 & 100 & 100.00 & 96.19 \\
\hline 9 & 0.0195 & 0 & 100 & 100.00 & 100.10 & 0 & 150 & 100.00 & 96.56 \\
\hline 10 & 0.0098 & 0 & 50 & 100.00 & 99.24 & 0 & 200 & 100.00 & 96.75 \\
\hline HCL & 0.0000 & 0 & 150 & 100.00 & 98.37 & 0 & 50 & 100.00 & 96.94 \\
\hline H20 & 0.0000 & 50 & 50 & 50.00 & 0.00 & 0 & 350 & 100.00 & 0.00 \\
\hline Total & & 200 & 900 & 87.50 & & 50 & 1550 & 97.22 & \\
\hline & & & & & & & & & \\
\hline
\end{tabular}

\begin{tabular}{|c|c|c|c|c|c|c|c|}
\hline & rameters & LC 50 (mcg) & $\begin{array}{c}\text { Ref. } 0.15 \mathrm{mcg} / \\
\mathrm{ml}(\%)\end{array}$ & & arameters & LC 50 (mcg) & $\begin{array}{c}\text { Ref. } 0.15 \mathrm{mcg} / \\
\mathrm{ml}(\%)\end{array}$ \\
\hline $\mathrm{a}$ & 88.69 & -0.5453 & 111.6700 & $\mathrm{a}$ & -19.25 & 2.4382 & 94.0555 \\
\hline $\mathrm{b}$ & 98.37 & & & $\mathrm{~b}$ & 96.94 & & \\
\hline
\end{tabular}

Note: A.i. conc. = active ingredient concentration, LC $50=$ lethal concentration 50,

Tab. 6. Group 2 EHA results for MBZ and TBZ

\begin{tabular}{cccccccccc}
\hline & & \multicolumn{9}{c}{ MBZ } & \multicolumn{3}{c}{ TBZ } \\
\cline { 3 - 11 } Sample no. $\begin{array}{c}\text { A.i. conc. } \\
(\mathrm{mcg} / \mathrm{ml})\end{array}$ & No. of eggs & L1 & $\begin{array}{c}\text { Hatching } \\
\%\end{array}$ & $\begin{array}{c}\text { Trend line } \\
\text { equation }\end{array}$ & No. of eggs & L1 & Hatching \% & $\begin{array}{c}\text { Trend line } \\
\text { equation }\end{array}$ \\
\hline 1 & 5.0000 & 0 & 50 & 100.00 & -85.15 & 50 & 0 & 0.00 & $-1,840.17$ \\
\hline 2 & 2.5000 & 0 & 50 & 100.00 & 3.85 & 150 & 0 & 0.00 & -911.00 \\
\hline 3 & 1.2500 & 0 & 250 & 100.00 & 48.35 & 50 & 0 & 0.00 & -446.41 \\
\hline 4 & 0.6250 & 0 & 50 & 100.00 & 70.60 & 50 & 0 & 0.00 & -214.11 \\
\hline 5 & 0.3125 & 50 & 0 & 0.00 & 81.73 & 50 & 0 & 0.00 & -97.97 \\
\hline 6 & 0.1563 & 0 & 100 & 100.00 & 87.29 & 50 & 0 & 0.00 & -39.91 \\
\hline 7 & 0.0781 & 0 & 100 & 100.00 & 90.07 & 150 & 0 & 0.00 & -10.85 \\
\hline 8 & 0.0391 & 0 & 100 & 100.00 & 91.46 & 50 & 0 & 0.00 & 3.65 \\
\hline 9 & 0.0195 & 0 & 150 & 100.00 & 92.16 & 50 & 0 & 0.00 & 10.93 \\
\hline 10 & 0.0098 & 0 & 50 & 100.00 & 92.50 & 50 & 0 & 0.00 & 14.54 \\
\hline HCL & 0.0000 & 0 & 100 & 100.00 & 92.85 & 0 & 50 & 100.00 & 18.18 \\
\hline H20 & 0.0000 & 0 & 50 & 100.00 & 0.00 & 0 & 50 & 100.00 & 0.00 \\
\hline Total & & 50 & 1050 & 91.67 & & 700 & 100 & 16.67 & \\
\hline
\end{tabular}

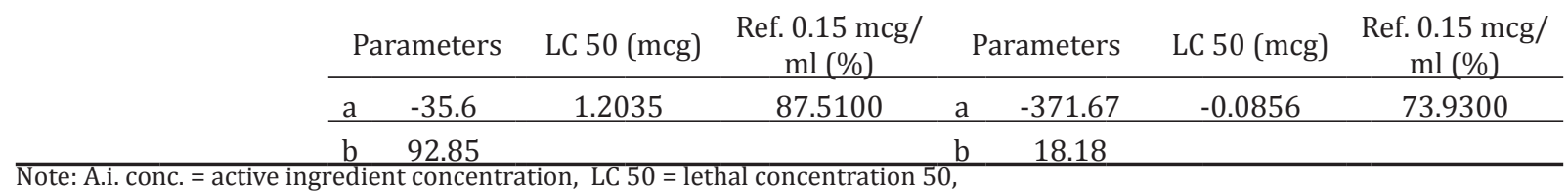




\section{CONCLUSIONS}

In the horse group, tested stool samples showed the predominance of small strongyles, especially those of Cyathostomum type A, Cyathostomum type D and Cyathostomum type
C. After the fenbendazole treatment, all stool samples were negative, showing the high efficacy of this active ingredient.

In the donkey group, we found Trichostrongylus axei, Cyathostomum type A, Cyathostomum type

Tab 7. Group 1 LDA results for ABZ and FBZ

\begin{tabular}{|c|c|c|c|c|c|c|c|c|c|}
\hline \multirow{2}{*}{\multicolumn{2}{|c|}{$\begin{array}{l}\text { A.i. conc. Sample no. } \\
(\mathrm{mcg} / \mathrm{ml})\end{array}$}} & \multicolumn{4}{|c|}{$\mathrm{ABZ}$} & \multicolumn{4}{|c|}{ FBZ } \\
\hline & & $\begin{array}{l}\text { Eggs } \\
+\mathrm{L} 1 \\
+\mathrm{L} 2 \\
\end{array}$ & L3 & Development \% & $\begin{array}{l}\text { Trend line } \\
\text { equation }\end{array}$ & $\begin{array}{l}\text { Eggs } \\
+\mathrm{L} 1 \\
+\mathrm{L} 2 \\
\end{array}$ & L3 & Development \% & $\begin{array}{l}\text { Trend line } \\
\text { equation }\end{array}$ \\
\hline 5.0000 & 1 & 250 & 0 & 0.00 & -525.46 & 650 & 0 & 0.00 & -849.21 \\
\hline 2.5000 & 2 & 400 & 0 & 0.00 & -260.14 & 150 & 0 & 0.00 & -420.41 \\
\hline 1.2500 & 3 & 50 & 0 & 0.00 & -127.47 & 350 & 0 & 0.00 & -206.01 \\
\hline 0.6250 & 4 & 300 & 0 & 0.00 & -61.14 & 450 & 0 & 0.00 & -98.81 \\
\hline 0.3125 & 5 & 350 & 0 & 0.00 & -27.98 & 350 & 0 & 0.00 & -45.21 \\
\hline 0.1563 & 6 & 150 & 0 & 0.00 & -11.40 & 300 & 0 & 0.00 & -18.42 \\
\hline 0.0781 & 7 & 650 & 0 & 0.00 & -3.10 & 450 & 0 & 0.00 & -5.01 \\
\hline 0.0391 & 8 & 250 & 0 & 0.00 & 1.04 & 850 & 0 & 0.00 & 1.68 \\
\hline 0.0195 & 9 & 100 & 0 & 0.00 & 3.12 & 250 & 0 & 0.00 & 5.05 \\
\hline 0.0098 & 10 & 300 & 0 & 0.00 & 4.15 & 400 & 0 & 0.00 & 6.71 \\
\hline 0.0000 & $\begin{array}{c}\text { Average } \\
\mathrm{H}_{2} \mathrm{O}+\mathrm{HCl}\end{array}$ & 375 & 150 & 28.57 & 5.19 & 175 & 150 & 46.15 & 8.39 \\
\hline \multicolumn{2}{|c|}{ MIC - mcg } & \multicolumn{4}{|c|}{$\begin{array}{l}\text { Z.60 } \\
\text { Parameters }\end{array}$} & \multicolumn{4}{|c|}{ Parameters } \\
\hline \multicolumn{2}{|c|}{0.0489} & & $\mathrm{a}$ & \multicolumn{2}{|c|}{-106.13} & $\frac{a}{b}$ & \multicolumn{3}{|c|}{-171.52} \\
\hline
\end{tabular}

Note: A.i. conc. = active ingredient concentration, MIC = Minimum inhibitory concentration

Tab 8. Group 1 LDA results for MBZ and TBZ

\begin{tabular}{|c|c|c|c|c|c|c|c|c|c|}
\hline \multirow[b]{2}{*}{$\begin{array}{l}\text { A.i. conc. } \\
(\mathrm{mcg} / \mathrm{ml})\end{array}$} & \multirow[b]{2}{*}{ Sample no. } & \multicolumn{4}{|c|}{ MBZ } & \multicolumn{4}{|c|}{ TBZ } \\
\hline & & $\begin{array}{l}\text { Eggs } \\
+\mathrm{L} 1 \\
+\mathrm{L} 2 \\
\end{array}$ & L3 & Development \% & $\begin{array}{l}\text { Trend line } \\
\text { equation }\end{array}$ & $\begin{array}{l}\text { Eggs } \\
+ \text { L1 } \\
+ \text { L2 } \\
\end{array}$ & L3 & Development \% & $\begin{array}{l}\text { Trend line } \\
\text { equation }\end{array}$ \\
\hline 5.0000 & 1 & 100 & 0 & 0.00 & -581.11 & 400 & 0 & 0.00 & -581.11 \\
\hline 2.5000 & 2 & 150 & 0 & 0.00 & -287.69 & 450 & 0 & 0.00 & -287.69 \\
\hline 1.2500 & 3 & 200 & 0 & 0.00 & -140.97 & 650 & 0 & 0.00 & -140.97 \\
\hline 0.6250 & 4 & 350 & 0 & 0.00 & -67.62 & 250 & 0 & 0.00 & -67.62 \\
\hline 0.3125 & 5 & 800 & 0 & 0.00 & -30.94 & 250 & 0 & 0.00 & -30.94 \\
\hline 0.1563 & 6 & 300 & 0 & 0.00 & -12.60 & 300 & 0 & 0.00 & -12.60 \\
\hline 0.0781 & 7 & 400 & 0 & 0.00 & -3.43 & 100 & 0 & 0.00 & -3.43 \\
\hline 0.0391 & 8 & 350 & 0 & 0.00 & 1.15 & 50 & 0 & 0.00 & 1.15 \\
\hline 0.0195 & 9 & 150 & 0 & 0.00 & 3.45 & 200 & 0 & 0.00 & 3.45 \\
\hline 0.0098 & 10 & 150 & 0 & 0.00 & 4.59 & 350 & 0 & 0.00 & 4.59 \\
\hline \multirow[t]{2}{*}{0.0000} & $\begin{array}{c}\text { Average } \\
\mathrm{H} 20+\mathrm{HCl}\end{array}$ & 325 & 150 & 31.58 & 5.74 & 325 & 150 & 31.58 & 5.74 \\
\hline & Total & 3275 & 150 & 2.87 & & 3325 & 150 & 2.87 & \\
\hline
\end{tabular}

\begin{tabular}{ccccc} 
MIC $-\mathrm{mcg}$ & \multicolumn{2}{c}{ Parameters } & \multicolumn{2}{c}{ Parameters } \\
\cline { 2 - 5 } 0.0489 & $\mathrm{a}$ & -117.37 & $\mathrm{a}$ & -117.37 \\
\cline { 2 - 5 } & $\mathrm{b}$ & 5.74 & $\mathrm{~b}$ & 5.74 \\
Note: A.i. conc. = active ingredient concentration, MIC = Minimum inhibitory concentration & &
\end{tabular}


D, but also Triodontophorus spp. Fenbendazole treatment had a reduced efficacy, the average intensity being $150 \mathrm{EPG}$ and the extensivity $50 \%$.

EHA revealed the efficacy of albendazole, fenbendazole and thiabendazole against the strongyles found in the horse group and the poor efficacy of mebendazole together with the risk of inducing adaptive phenomena. In the donkey group, EHA showed a low efficacy for all benzimidazoles against the tested strongyles.

LDA revealed that, in both groups, benzimidazoles inhibited larval development, with high efficacy.

Predictive risk analysis showed the fact that new therapeutic protocols that provide a prolonged contact of the benzimidazoles with the parasitic forms should be performed. Anthelmintic

Tab 9. Group 2 LDA results for ABZ and FBZ

\begin{tabular}{|c|c|c|c|c|c|c|c|c|c|}
\hline \multirow[b]{2}{*}{$\begin{array}{l}\text { A.i. conc. } \\
(\mathrm{mcg} / \mathrm{ml})\end{array}$} & \multirow[b]{2}{*}{ Sample no. } & \multicolumn{4}{|c|}{$\mathrm{ABZ}$} & \multicolumn{4}{|c|}{ FBZ } \\
\hline & & $\begin{array}{l}\text { Eggs } \\
+\mathrm{L} 1 \\
+\mathrm{L} 2 \\
\end{array}$ & L3 & Development \% & $\begin{array}{l}\text { Trend line } \\
\text { equation }\end{array}$ & $\begin{array}{l}\text { Eggs } \\
+\mathrm{L} 1 \\
+\mathrm{L} 2 \\
\end{array}$ & L3 & $\begin{array}{c}\text { Development } \\
\%\end{array}$ & $\begin{array}{c}\text { Trend line } \\
\text { equation }\end{array}$ \\
\hline 5.0000 & 1 & 50 & 0 & 0.00 & $-1,104.10$ & 50 & 0 & 0.00 & $-1,226.83$ \\
\hline 2.5000 & 2 & 50 & 0 & 0.00 & -546.60 & 50 & 0 & 0.00 & -607.36 \\
\hline 1.2500 & 3 & 100 & 0 & 0.00 & -267.85 & 50 & 0 & 0.00 & -297.62 \\
\hline 0.6250 & 4 & 50 & 0 & 0.00 & -128.48 & 100 & 0 & 0.00 & -142.75 \\
\hline 0.3125 & 5 & 50 & 0 & 0.00 & -58.79 & 50 & 0 & 0.00 & -65.31 \\
\hline 0.1563 & 6 & 150 & 0 & 0.00 & -23.95 & 100 & 0 & 0.00 & -26.61 \\
\hline 0.0781 & 7 & 200 & 0 & 0.00 & -6.52 & 100 & 0 & 0.00 & -7.23 \\
\hline 0.0391 & 8 & 150 & 0 & 0.00 & 2.18 & 100 & 0 & 0.00 & 2.43 \\
\hline 0.0195 & 9 & 50 & 0 & 0.00 & 6.55 & 150 & 0 & 0.00 & 7.29 \\
\hline 0.0098 & 10 & 150 & 0 & 0.00 & 8.71 & 200 & 0 & 0.00 & 9.69 \\
\hline 0.0000 & $\begin{array}{c}\text { Average } \\
\mathrm{H} 2 \mathrm{O}+\mathrm{HCl}\end{array}$ & 100 & 150 & 60.00 & 10.90 & 75 & 150 & 66.67 & 12.12 \\
\hline & Total & 1100 & 150 & 5.45 & & 1025 & 150 & 6.06 & \\
\hline \multirow{3}{*}{$\begin{array}{c}\text { MIC - mcg } \\
0.0489 \\
\end{array}$} & & \multicolumn{4}{|c|}{ Parameters } & \multicolumn{4}{|c|}{ Parameters } \\
\hline & & & $\underline{a}$ & & -223 & & $\mathrm{a}$ & & -247.79 \\
\hline & & & b & & 10.9 & & b & & 12.12 \\
\hline
\end{tabular}

Tab 10. Group 2 LDA results for MBZ and TBZ

\begin{tabular}{|c|c|c|c|c|c|c|c|c|c|}
\hline \multirow[b]{2}{*}{$\begin{array}{l}\text { A.i. conc. } \\
(\mathrm{mcg} / \mathrm{ml})\end{array}$} & \multirow[b]{2}{*}{ Sample no. } & \multicolumn{4}{|c|}{ MBZ } & \multicolumn{4}{|c|}{ TBZ } \\
\hline & & $\begin{array}{l}\text { Eggs } \\
+\mathrm{L} 1 \\
+\mathrm{L} 2\end{array}$ & L3 & Development \% & $\begin{array}{l}\text { Trend line } \\
\text { equation }\end{array}$ & $\begin{array}{l}\text { Eggs } \\
+\mathrm{L} 1 \\
+\mathrm{L} 2\end{array}$ & L3 & Development \% & $\begin{array}{l}\text { Trend line } \\
\text { equation }\end{array}$ \\
\hline 5.0000 & 1 & 100 & 0 & 0.00 & $-1,104.10$ & 250 & 0 & 0.00 & $-1,104.10$ \\
\hline 2.5000 & 2 & 50 & 0 & 0.00 & -546.60 & 100 & 0 & 0.00 & -546.60 \\
\hline 1.2500 & 3 & 50 & 0 & 0.00 & -267.85 & 50 & 0 & 0.00 & -267.85 \\
\hline 0.6250 & 4 & 100 & 0 & 0.00 & -128.48 & 200 & 0 & 0.00 & -128.48 \\
\hline 0.3125 & 5 & 50 & 0 & 0.00 & -58.79 & 150 & 0 & 0.00 & -58.79 \\
\hline 0.1563 & 6 & 50 & 0 & 0.00 & -23.95 & 100 & 0 & 0.00 & -23.95 \\
\hline 0.0781 & 7 & 100 & 0 & 0.00 & -6.52 & 100 & 0 & 0.00 & -6.52 \\
\hline 0.0391 & 8 & 150 & 0 & 0.00 & 2.18 & 100 & 0 & 0.00 & 2.18 \\
\hline 0.0195 & 9 & 50 & 0 & 0.00 & 6.55 & 100 & 0 & 0.00 & 6.55 \\
\hline 0.0098 & 10 & 100 & 0 & 0.00 & 8.71 & 200 & 0 & 0.00 & 8.71 \\
\hline \multirow[t]{2}{*}{0.0000} & $\begin{array}{c}\text { Average } \\
\mathrm{H} 20+\mathrm{HCl}\end{array}$ & 100 & 150 & 60.00 & 10.90 & 100 & 150 & 60.00 & 10.90 \\
\hline & Total & 900 & 150 & 5.45 & & 1450 & 150 & 5.45 & \\
\hline \multicolumn{2}{|c|}{ MIC - mcg } & \multicolumn{4}{|c|}{ Parameters } & \multicolumn{4}{|c|}{ Parameters } \\
\hline \multicolumn{2}{|c|}{0.0489} & & $\frac{a}{b}$ & & $\frac{-223}{109}$ & & $\frac{a}{b}$ & & $\frac{-223}{109}$ \\
\hline
\end{tabular}

Note: A.i. conc. $=$ active ingredient concentration, MIC = Minimum inhibitory concentration 
treatments should be performed regularly and verified using both in vitro and in vivo tests.

\section{REFERENCES}

1. Cernea M, Cernea L Cristina, Cozma V (2010). Chemoresistance at veterinary anthelmintics, AcademicPres Pubisher, Cluj-Napoca,

2. Cernea M, Chereji Anca, Cătană Laura (2015). Pharmacological basis of veterinary medical therapeutics, AcademicPres Pubisher, Cluj-Napoca, Pages 325-343

3. King AI, Love S, Duncan JL (1990). Field investigation of anthelmintic resistance of small strongyles in horses,Vet. Rec., Volume 127 (9), Pages 232-233.

4. Madeira de Carvalho LM, Farrim MC, Afonso-Roque MM, Fazendeiro MI (2003). Groups, efficacy and egg reappearance period of commonly used anthelmintics in equine practice in Portugal. J. Vet Pharm Therap, Volume 26, Suppl.1pages 237-238.

5. Madeira de Carvalho LM, Sousa S, Cernea M, Cernea LC, Arias M, Paz A (2014) Horses Breeding, health disorders and effects on performance and behaviour, SilvaEd. Nova Publisher, New York

6. Motulsky HJ, Platt M, Pilkington J, (1999). Guide to choosing and interpreting statistical tests,GraphPad Software. Inc, USA.

7. Smith MA, Nolan TJ, Rieger R, Aceto H, Levine DG, Nolen-Walston R, Smith BI (2015). Efficacy of major anthelmintics for reduction of fecal shedding of strongyletype eggs in horses in the Mid-Atlantic region of the United States, Veterinary Parasitology, Volume 214, Issues 1-2, Pages 139-143. 